\title{
COVID-19: Anthropocene and Capitalocene Caused Pandemics
}

Madhusudan Subedi

\begin{abstract}
Most epidemiological studies focus on the direct causes of diseases while wider, social causal factors are ignored. This paper briefly highlights the history of major epidemics and the role of Anthropocene and Capitalocene for the emergence and reemergence of pandemics like COVID-19. Books, journal articles, and statistics offer information that can explain the phenomena. A historical inquiry can inform us about the fundamental causes of pandemics. Human security and ecology are intertwined, and the global effect of pandemics responded to at the national level is inadequate. The lessons from the past and present help us devise effective ethically and socially appropriate strategies to mitigate the threats. If the present crisis is not taken seriously at the global level, the world has to face more difficult challenges in years to come.
\end{abstract}

Keywords: Anthropocene, Capitalocene, epidemics, planetary health

\section{Introduction}

Epidemiological studies have been immensely effective in identifying risk factors for major morbidity and mortality by emphasizing individually based risk factors, giving attention to personal protective measures (Link \& Phelan, 1995). However, the focus on risk factors gives only the proximate causes of drinking and smoking habits, dietary practices, cholesterol level, hypertension, and other lifestyle-related issues (McMichael, 1999).

Social scientists are deeply concerned about the social causes of mortality and morbidity. The identification of such causes is viewed as the basis for understanding historically shaped social phenomena (Marini \& Singer, 1988). Social analysis enables us to explain what has happened in the past, why it is happening in the present, what will happen in the future, and suggest possible measures for improvements (Bryman 2016). Such historically based assessments can explain the context of various events, enabling us to comprehend why particular events occurred at a particular time (Bernard \& Bernard, 2013). Causal inferences are useful in finding evidence in similar societies. There have been tremendous developments and changes in capitalism, industrialization, globalization, urbanization, climate change, livelihood diversification, and changes in food habits. The presence of transport hubs, availability and popularity of public transport, a large shopping and entertainment centers, and the construction of megacities have facilitated the destruction of natural habitats of plants and animals, and the transmission of infectious diseases. Such social phenomena are causal factors for the pandemics, and most of such phenomena can be observed, measured, and logically explained (Neuman, 2007).
The outbreak of the coronavirus disease (COVID-19) has brought about global concern. The pandemic has impacted humankind worldwide and has affected multiple sectors. To break the chain of its transmission, countries have imposed various restrictive measures. The major interventions applied to tackle the COVID-19 have been lockdown, testing, contact tracing, isolation management, treatment for severely affected patients, human resource management, supply chain management, provision of an ambulance and patient transport, mobilization of community volunteers, and dead body management.

These interventions are implemented to manage the pandemic. However, the causal social factors for the pandemic have not been sufficiently discussed and taken seriously. A historical discussion of pandemics enables us to gain systematic knowledge about how they have developed. A critical social science analysis offers a better understanding of our shared past so that we more appropriately can construct a world in which all of us can live well.

In this paper, I argue from a perspective that seeks to explain the link between social factors and the emergence of diseases which leads to instability, uncertainty, and crisis (Link \& Phelan, 1995; Link \& Phelan, 2002; Dingwall et al., 2013). I focus on how the population dynamics, environmental degradation, air and water pollution and consequences, biodiversity loss, and land-use changes have contributed to habitat loss, expanding the humanwildlife interface, and facilitating the spread of zoonotic diseases such as COVID-19.

The virus has spread from Wuhan, China, to every continent except Antarctica. On January 30, 2020, the World Health Organization declared the outbreak a public health emergency of international concern (World Health 
Organization [WHO], 2020), and it was recognized as a pandemic on the March 11, 2020. The virus has been responsible for millions of infections and deaths globally. As of November 22, 2020, COVID-19 has affected 218 countries, and the total number of infected and death cases are 58,449,801 and 1,386,570 respectively (Worldometers, 2020).

Health scientists say that COVID-19 mainly spread during close contact, and by small droplets produced during coughing, sneezing, or talking. These small droplets may also be produced during breathing. The droplets rapidly fall to the ground or onto surfaces and are not generally airborne over large distances (Wiersinga et al., 2020). People may also catch COVID-19 by touching a contaminated surface and then their face. The time between exposure and symptom onset is around 5 days but may range from two to fourteen days. Common symptoms include fever, cough, and shortness of breath (Sah, 2020). Thus, preventive measures are recommended that include the use of masks in public places, handwashing, maintain physical distance from other people, monitoring and selfquarantine for people who suspect they may be infected.

The exact cause of COVID-19 is yet to be investigated but many health scientists assume that a new strain of coronavirus likely originated in bats or pangolins. However, it is unclear exactly how the virus first spread to humans. The most likely cause is the result of the eating habits of live animals (Chavez, 2020).

Globalization has led to people living closer to each other, and that we use similar products and technology. It has created challenges and pressures to explain social phenomena in a broad global perspective. The emergence of infectious diseases is a product of human-nature relationships, and, today, the COVID-19 pandemic is one of the most severe challenges faced in human history. While waiting for a vaccine, the major focus has been on the universal wearing of masks, avoiding crowds, maintaining physical distance, and washing hands.

\section{Methods and Materials}

Social scientists have used comparative-historical methods to obtain insight into diverse social phenomena and significantly contributed to our understanding of perplexing and pertinent social issues (Kiser \& Hechter, 1991; Mahoney, 2003; Mahoney, 2004; Lange, 2012).

Anthropocene and Capitalocene are the fundamental social conditions that cause diseases, especially pandemics, including COVID-19. The paper's material consists of archival data, secondary sources, and ongoing series of statistics. These sources provide crucial information for proposing potential causes for the phenomena.

\section{Findings and Discussion}

\section{A Brief History of Epidemics}

Social scientists and especially historians are asked how lessons of the past can help us to respond to the
COVID-19. How do epidemics begin and end? Will our society be transformed? History does not simply provide a stimulating context to our thoughts on the present problem; it also supplies an essential part of the information which must be taken into consideration in order to make these thoughts really fruitful (Vermeir, 2020).

Communicable diseases existed during the huntinggathering days, but the shift to agrarian life 10,000 years ago created communities that made epidemics more possible (Barker, 2009). To provide food for an increasing population, people started to domesticate plants and animals and encroach forest land for agriculture. Disturbances of natural habitats created conducive environments for viruses to transmit from animals to humans. Since the huntergatherer settled in specific areas, infectious diseases have killed more people than war and famine (Karlen, 1996). Throughout the known history there have been periodic pandemics that each shaped our history and society, and also the basic principles of health sciences.

The first recorded pandemic was the Athenian plague which occurred in 430-26 BC. It originated in Ethiopia and spread throughout Egypt and Greece. Wartime and overcrowding were the major factors in the transmission of disease in the city of Athens. The plague spread quickly and most of the population was infected in the overcrowded city areas (Huremovic, 2019). The Athens plague affected a majority of the inhabitants of the city-states and claimed as many as 75,000 to 100,000 dead people, more than $25 \%$ of the population (Littman, 2009).

Another outbreak, known as the Antonine Plague, occurred in 165-180 AD in the Roman Empire. Because the Roman Empire was economically and politically integrated, the plague spread across the vast territory of the entire Empire. The plague destroyed more than one-third of the population in some areas. The impact of the plague on the Roman Empire was severe, declining its military and economic domination (Huremovic, 2019).

The Justinian plague originated in the mid-sixth century, either in Ethiopia, moving through Egypt, or on the Central Asian steppes, where it then followed trading routes (Ligon, 2006). Military movements at the time also contributed to spreading the disease from Asia to Africa, and Europe. Due to the plague, all trade was abandoned in urban areas, staple food became insufficient, and people died of hunger as well as of the disease. After the initial outbreak in 541, the plague was repeated many times. By 600 , the population of the Empire had been reduced by 40\% (Huremovic, 2019).

Another devastating epidemic recorded in human history was the Black Death. It originated in China in 1334 and spread to Europe in 1347 . Within 50 years, by 1400 , it reduced the global population from 450 million to possibly below 300 million (Huremovic, 2019). Some estimate that the Black Death claimed up to 60 percent of the population in Europe at that time (Herlihy, 1997; Gottfried, 2010).

The Black Death led to major economic transformations. The depopulation eroded peasants' obligation to remain in their traditional landlord-peasant relationship. Such economic relationships resulted from the roots of capitalism 
(Ligon, 2006). It reversed the pre-epidemic conditions of an excess population relative to resources (DeWitte, 2014). Thus, standards of living improved after the epidemic, at least in some areas of Europe, such as England. The plague dismissed the normal divisions between the rich and poor classes and led to the emergence of a new middle class. The scarcity of human labor encouraged innovation of labor-saving technologies, leading to higher productivity (Huremovic, 2019)

The Spanish flu (1918-19) is considered one of the major global pandemics in history. It is estimated that 30 percent of the world population was infected and that at least 50 million people died (Esparza, 2020). This figure was higher than the number of people killed in the First World War. The Spanish flu had an immense influence on the health system. Many countries started to keep records of disease surveillance and vital statistics to prevent future pandemics. However, adequate attention was not given to the causes of pandemics. There were two other flu pandemics, the 1957 Asian flu and the 1968 Hong Kong flu. These pandemics killed 2 million and 4 million people respectively (Whiting 2020).

The world is highly connected and viruses can spread in a very short time. Various pandemics seem on the rise in recent decades. For example, HIV/AIDS (1981), SARS (2002), Bird Flu (2003), Swine Flu (2009), MERS (2012), Ebola (2014), and Zika (2015). The impact of these pandemics has been different in different places and people. The current world has become more complex and connected in terms of population size and density, social relations, transportation infrastructure, and medical care (Jones 2020). The increasing transmission of diseases from wildlife to humans reflects the pressure we are putting on the planet (United Nations Development Programme, 2020).

In December 2019, a new coronavirus (COVID-19) emerged in Wuhan, China. It has affected 218 countries. By mid-November 2020, more than 57 million people are infected and 1.35 million deaths have been reported due to COVID-19 (Worldometers, 2020). To slow the spread of the virus, the use of masks in public, hand washing, and physical distancing have been the major interventions. However, there has not been serious attention to the real causes of such pandemics.

These historical events clearly show that in most of the scientific inquiries, microbes are viewed as pathogenic agents, that is, powerful actors that caused crippling diseases for crops, livestock, and humans. However, the environmental and social contexts are not adequately discussed. The study of material, social and environmental conditions for pandemics are often ignored (D'Abramo \& Neumeyer, 2020), not giving adequate attention to microorganisms as threats to human and non-human health. Nobody would disagree that disease pathology is explained through the transmission of a specific microbe, but the causes for epidemic outbreaks can be better understood by bringing in a broader ecological and social context. The environmental destruction, habitat loss, over-exploitation of natural resources, and the ecological dimension of microorganisms have been the crucial biological forces behind various pandemics in the past.

Epidemics are not only a function of pathogens; they are also results of how society is structured and is functioning, how political power is exercised in the name of population health, how quantitative and qualitative data are collected and interpreted, how diseases are categorized and modeled, and how histories of diseases are narrated (Trostle, 2005; Nichter, 2008). Each of them has causal relations and social importance.

\section{Anthropocene}

The Anthropocene describes the effect of the human species and their technological desires. It highlights the population growth, economic activity, mechanizations, exploitation of natural resources, and changes in the biophysical environment (Crutzen \& Stoermer, 2000, Steffen et al., 2015). Until the $15^{\text {th }}$ Century, most of the people in the world lived in predominantly agricultural societies. Interconnections between societies were relatively few, and changes were slow for the vast majority of human history. About 500 years ago, improved boats were used to carry people and goods from one continent to another more frequently. Migration, colonization, exchange of goods across the great oceans, and slave trade began. The economy was dominated by labor work with soil, rainfall, sunlight to produce food, fiber, and shelter for the family and others (Norgaard, 2013).

Climate change has increasingly made people aware of its influence on the environment throughout the world (Steffen et al., 2011). The emission of large quantities of carbon dioxide (CO2) can affect the energy balance at the earth's surface. This has reinforced the concern that human activity can adversely affect the broad range of ecosystem services that support human and other life, eventually leading to a 'crisis in the biosphere'. As a result, monsoon has been disrupted and less predictable, and the farmers who are heavily dependent on monsoon are heavily suffering. Furthermore, humans are significantly altering several other bio-chemicals such as nitrogen, phosphorus, and sulfur that are fundamental to life on the earth. Such activities could also have major unforeseen consequences in the future.

Human activities are the most dominant cause of most contemporary environmental change (Lewis and Maslin, 2015). There have been so many changes in ecology, especially after the Second World War. The biodiversity loss, climate change, ocean acidification, changes in land use, and chemical pollution have rapidly happened due to worldwide industrialization, technoscientific development, nuclear arms race, population explosion, and rapid economic growth (Steffen et al., 2011). Thus, it clearly can be seen that the human activities are affecting the environment, from earth's major biogeochemical cycles to the evolution of life. The development of diverse products, including antibiotics, pesticides, and novel genetically engineered organisms alongside the movements of species to new habits, intense harvesting, and the selective pressure 
of higher air temperatures resulting from greenhouse emissions, are all likely to alter evolutionary outcomes (Lewis \& Maslin, 2015).

Human actions also affect non-human life. The landuse conversion to produce food, fuel, fiber, and fodder, combined with targeted hunting and harvesting, have resulted in species extinctions. Industrial food production is responsible for increasing the fragility of ecosystems that harmed the planet and created conducive environments for the current pandemic to emerge. Organisms have been transported around the world including crops, domesticated animals, and pathogens on land. Similarly, boats have transferred organisms between once-disconnected oceans (Lewis \& Maslin, 2015).

There has been an increasing recognition of the long history of human interactions with tropical forests and the extensive decrease of plant and animal species and populations in forests (Malhi et al., 2014). Tropical forests are ruined through burning for hunting and clearance for agriculture, and changes in desert areas has important implication for climate change (Mahowald, 2007).

The current phase of Anthropocene is the long-term rise in surface temperature, caused by the increased concentration of atmospheric greenhouse gases (Ruddiman, 2013). In deforesting regions, warming is also exacerbated by the direct loss of vegetation cover, which results in a decrease in land-surface evaporation and changes in cloud formation, persistence, and reflectance (Ainsworth et al., 2012, Malhi et al., 2014).

In conclusion, forests were destroyed, habitats of animals and plants were damaged, food habits changed, settlement of densely populated areas increased, and human-made ecological disruption substantially increased. Due to such biodiversity and land system changes, viruses lost their natural hosts due to disrupted ecosystems. People and animals started to live in closer proximity and the risk increased to jump viruses from animals to humans. Such social conditions facilitated for pandemics like COVID-19.

The Anthropocene perspective has not been able to explain how the present crisis is unfolding. It shows the empirical changes over time but does not highlight the sign of danger to explain how we have arrived at the moment of planetary crisis (Moore, 2017). If we wish to explain the relationships between power, capital, and nature, we have to make a deeper analysis of capital, power, and reproduction. Such analysis is called the perspective of world-ecology or Capitalocene (Moore, 2017).

\section{Capitalocene}

World ecology is a way to think about human history in the web of life. Capitalism is a set of relationships between power, capital, and nature. Capitalism creates an ecology that expands across the planet through its frontiers driven by forces of endless accumulation.

Together with capitalism, Capitalocene represents a way of organizing nature as a multispecies, situated, capitalist world-ecology (Moore, 2016). There have been many other concepts such as Anthrobsene (Parikka, 2014),
Econocene (Norgaard 2013), Technocene (Hornborg, 2015), and Misanthropocene (Patel, 2013). All are useful. Anthrobscene is a concept to describe the effects of the human species and its scientific-technological needs on the planet (Parikka, 2014). Econocene focuses on corporations being hierarchies, and that they are bigger and more important than ever before in human history. This is an era in which our economy has become the major driver of rapid global change (Norgaard, 2013). Technocene highlights technological progress as natural (Hornborg, 2015). But none of these concepts capture the basic modern pattern as the "Age of Capital" and the era of capitalism as a worldecology of power, capital, and nature (Moore, 2016).

Capitalocene allows us to see how the modern world's violent and exploitative relationships are rooted in five centuries of capitalism, and also how these unequal arrangements are contingent and in the midst of an unprecedented crisis (Moore, 2010). Through the transnational capital flows, international and multinational organizations, increasing fluidity in terms of social and cultural capital, and the essential components of the state - borders, sovereignty, and autonomy - are challenged. Borders have become fluid, sovereignty is contested, and autonomy is shared. The Capitalocene has created an accumulation of resources, concentration of political and economic power in a few countries, the production of nuclear energy, and hyper-consumption of goods and services, and trade of rare species. Thus, it is clear that humans are responsible for the current level of ecological destruction. In this situation, the animals are forced to leave their habitats and they are coming into physical contact with humans. The air and land networking are the facilitators of the rapid spread of viruses.

\section{Are Anthropocene and Capitalocene Mutually Exclusive?}

Arjun Appadurai (1996) explains the new global cultural economy as a complex, overlapping, disjunctive order of ethnoscapes, mediascapes, technoscapes, financescapes, and ideoscapes. These were the products of both Anthropocene and Capitalocene, both being responsible for the exploitation of natural resources, loss of wild habitat, and climate change.

Bacteria and viruses are conceived as fundamental elements necessary to all forms of life and which, throughout more than 4,000 million years, have combined and transformed basic chemical and biochemical elements to give rise to complex forms of life (D'Abramo \& Neumeyer, 2020). The recent attention is shifting notions of microorganisms as threats to human and non-human health by acknowledging their key roles in earth systems. To accumulate capital, rich individuals, developed countries, and corporate houses exploit and consume carbonburning energy for their profit and growth. Anthropocene and Capitalocene are not only accelerating for the rise in temperature, species and habitat loss, air and water pollution, but they also contribute to the transmission of viruses from animal to animal, animal to human, and from 
human to human at the global level.

Anthropocene and Capitalocene clearly show that the 'planetary health' is in the current critical situation due to biodiversity losses, climate change, and environmental degradation. The planetary health perspective emphasizes that health can be better understood in a broad and integrated way (Ullman, 1979). This perspective has been discussed in social-ecology and anthropology as well as by various environmental advocacy groups. The focus is on planetary health, the health of natural systems within the biosphere (Prescott \& Logan, 2019).

There is hope in the world ecology. If one draws the observation further, the conclusion is that human security and ecology are intertwined. While the effect has been global, the response has been national. Available evidences depict that the closing of borders, restrictions on international travel, lockdown, use of face mask, hand washing, and maintaining physical distancing against COVID-19 are the temporary solutions. If not taken seriously, a new pathogen can cause dreadful devastations and lead to the deaths of millions.

\section{Conclusion}

Several theories on the origin of the pandemics and related social conditions exist. These theories are not mutually exclusive. Evidences exist to support that different viruses may have developed in different ways. The future of the earth and its population is being determined by the actions of humans (Lewis and Maslin 2015: 178). During recent centuries, destructive activities have spread at an increasing rate all over the globe.

The emergence of infectious diseases is a product of human-nature relationships, and, today, the COVID-19 pandemic has offered the world with a joint action to resolve the problems. The challenge for both scholarship and politics is to think for a wider benefit for humankind and act across the vast and complex web of short-term and long-term causes and consequences. The pandemic has shown us how interconnected the world is and how important it is for global leadership to work collectively on issues such as the use of natural resources, health and recovery, migration, illegal wildlife trade, and climate change.

The frequent occurrence of pandemics has emphasized the fact that unregulated exploitation of natural resources coupled with unsustainable food habits and consumption patterns lead to the destruction of the system that supports human life.

The continual worsening and dreadful conditions of the world's ecosystem have major impacts on the lives and livelihoods of a large number of populations everywhere. Degradation of nature is not purely an environmental issue. It spans economics, public health, equity and social justice, and basic human rights. The life-supporting infrastructure of the earth may have increasing philosophical, social, economic, and political implications over the coming decades (Lewis and Maslin 2015).

For the short term, we need a vaccine for the COVID-19.
However, if the Anthropocene and Capitalocene are not taken seriously, another pandemic will certainly occur and most probably kill more people. The overall impact would be massive. A comprehensive response to Anthropocene is that we need new tools for fighting climate change. In other words, the effects of Anthropocene and Capitalocene will almost certainly be harsher than COVID-19 and be worse for people who least caused them. The countries and people that are contributing to the disequilibrium of the human-environment relationships and also benefitting from these changes should take the responsibility to solve the problem. COVID-19 has given us a warning to avoid mistakes that can prevent better conditions for living creatures and nature. Otherwise, other pandemics are inevitable. The world should now look at a global problem demanding global solutions.

The COVID-19 pandemic clearly has shown that the current public policy and health care systems are inadequate to deal with the challenges. The pandemic does not have any nationality or specific political boundaries. The coordination of preventive activities at a global level is urgent to collectively fight against the pandemic. Social scientists, public health professionals, and civil society members have a responsibility to draw the attention of political leaders and international organizations for minimizing the influence of Anthropocene and Capitalocene to prevent more dangerous pandemics. If steps are not taken collectively and seriously, the possibility for more dangerous pandemics in the future is high. We should be ready to face such challenges on a global scale.

\section{Acknowledgment:}

This paper was presented in National Webinar on "Controlling COVID-19: Lessons from Practitioners in Health, Governance and Social Science" organized by Professor Chaitanya Mishra Foundation for Social Sciences (Kathmandu, 21 November 2020). I am indebted to Professor Emerita Marit Bakke for her feedback and suggestions. I thank Assistant Professor Man Bahadur Khattri and the anonymous reviewers for their careful reading of the manuscript and insightful comments and suggestions.

\section{Funding:}

Not funded by any individual or organization.

\section{Ethical Approval for the research:}

Ethical approval is not applicable for review article.

\section{Conflict of interest:}

There is no conflict of interest.

Ethical conduct of research:

I declare that this study has been conducted ethically. 


\section{References}

Ainsworth, E. A., Yendrek, C. R., Sitch, S., Collins, W. J., \& Emberson, L. D. (2012). The effects of tropospheric ozone on net primary productivity and implications for climate change. Annual Review of Plant Biology, 63, 637-661.

Appadurai, A. (1996). Modernity al large: cultural dimensions of globalization. University of Minnesota Press.

Barker, G. (2009). The agricultural revolution in prehistory: Why did foragers become farmers? Oxford University Press.

Bernard, H. R., \& Bernard, H. R. (2013). Social research methods: Qualitative and quantitative approaches. Sage.

Bryman, A. (2016). Social research methods. Oxford University Press.

Chavez, S., Long, B., Koyfman, A., \& Liang, S. Y. (2020). Coronavirus Disease (COVID-19): A primer for emergency physicians. The American Journal of Emergency Medicine. [accessed 2020 November 22. Retrieved from: https://www.ajemjournal.com/article/ S0735-6757(20)30178-9/fulltext

Crutzen P.J. (2006) The "Anthropocene". In: Ehlers E., Krafft T. (Eds) Earth System Science in the Anthropocene (pp 13-18). Springer.

Crutzen, P. J., \& Stoermer, E. F. (2000). The Anthropocene IGBP newsletter, 41. Royal Swedish Academy of Sciences.

D'Abramo, F., \& Neumeyer, S. (2020). A historical and political epistemology of microbes. Centaurus, 62(2), 321-330.

DeWitte, S. N. (2014). Mortality risk and survival in the aftermath of the medieval Black Death. PloS one, 9(5), e96513.

Dingwall, R., Hoffman, L. M., \& Staniland, K. (Eds.). (2013). Pandemics and emerging infectious diseases: The sociological agenda. John Wiley \& Sons.

Gottfried, R. S. (2010). Black Death. Simon and Schuster.

Herlihy, D. (1997). The Black Death and the transformation of the West. Harvard University Press.

Huremović, D. (Ed.) (2019). Psychiatry of Pandemics. Springer.

International Centre for Integrated Mountain Development [ICIMOD]. (2020). COVID-19 impact and policy responses in the Hindu Kush Himalaya. International Centre for Integrated Mountain Development, Nepal or elsewhere.

Esparza, J. (2020). Lessons From History: What Can We Learn From 300 Years of Pandemic Flu That Could Inform the Response to COVID-19? American Journal of Public Bealth, 110(8), 1160-1161.

Jones, D. S. (2020). COVID-19, history, and humility. Centaurus, 62(2), 370-380.

Karlen, A. (1996). Man and microbes: disease and plagues in history and modern times.

Simon and Schuster.Kiser, E., \& Hechter, M. (1991). The role of general theory in comparative-historical sociology. American Journal of Sociology, 97(1), 1-30.

Lange, M. (2012). Comparative-historical methods. Sage.

Lewis, S. L., \& Maslin, M. A. (2015). Defining the Anthropocene. Nature, 519(7542), 171-180.

Ligon, B. L. (2006, July). Plague: a review of its history and potential as a biological weapon. Seminars in Pediatric Infectious Diseases, 17(3),161-170.

Link, B. G., \& Phelan, J. (1995). Social conditions as fundamental causes of disease. Journal of Health and Social Behavior, 35, 80-94.

Link, B. G., \& Phelan, J. C. (2002). McKeown and the idea that social conditions are fundamental causes of disease. American journal of public health, 92(5), 730732.

Littman, R. J. (2009). The plague of Athens: epidemiology and paleopathology. Mount Sinai Journal of Medicine: A Journal of Translational and Personalized Medicine: , 76(5), 456-467.

Mahoney, J. (2003). Strategies of causal assessment in comparative historical analysis. Comparative historical analysis in the social sciences, 337-372.

Mahoney, J. (2004). Comparative-historical methodology. Annual Review of Sociology, 30, 81-101.

Mahowald, N. M. (2007). Anthropocene changes in desert area: Sensitivity to climate model predictions. Geophysical Research Letters, 34(18).

Malhi, Y., Gardner, T. A., Goldsmith, G. R., Silman, M. R., \& Zelazowski, P. (2014). Tropical forests in the Anthropocene. Annual Review of Environment and Resources, 39.

Marini, M. M., \& Singer, B. (1988). Causality in the social sciences. Sociological Methodology, 18, 347-409.

McMichael, A. J. (1999). Prisoners of the proximate: loosening the constraints on epidemiology in an age of change. American journal of epidemiology, 149(10), 887-89.

Moore, J. (2010). Cheap Food \& Bad Money: Food, Frontiers, and Financialization in the Rise and Demise of Neoliberalism. Review, 33(2/3), 225-261.

Moore, J. Ed. (2016). Anthropocene or Capitalocene? Nature. History, and the Crisis of Capitalism. PM Press.

Moore, J. W. (2017). The Capitalocene, Part I: on the nature and origins of our ecological crisis. The Journal of peasant studies, 44(3), 594-630.

Neuman, L. W. (2007). Social research methods, 6/E. Pearson Education.

Nichter, M. (2008). Global health: Why cultural perceptions, social representations, and biopolitics matter. University of Arizona Press.

Norgaard, R. B. (2013). Escaping economism, escaping the Econocene. Economy of sufficiency. Wuppertal Institute for Climate, Environment and Energy, Wuppertal, 44-52.

Parikka, J. (2014). The Anthrobscene. University of Minnesota Press.

Prescott, S. L., \& Logan, A. C. (2019). Planetary health: from the wellspring of holistic medicine to personal and public health imperative. Explore, 15(2), 98-106. 
Ruddiman, W. F. (2013). The Anthropocene. Annual Review of Earth and Planetary Sciences, 41, 45-68.

Sah, R., Pokhrel, N., Fathah, Z., Ozaki, A., Bhandari, D., Kotera, Y., \& Patel, S. K. (2020). SARS-Cov-2/ COVID-19: Salient Facts and Strategies to Combat Ongoing Pandemic. Journal of Pure and Applied Microbiology, 14(3).

Steffen, W., Broadgate, W., Deutsch, L., Gaffney, O., \& Ludwig, C. (2015). The trajectory of the Anthropocene: The great acceleration. The Anthropocene Review, 2(1), 81-98.

Steffen, W., Grinevald, J., Crutzen, P., \& McNeill, J. (2011). The Anthropocene: conceptual and historical perspectives. Philosophical Transactions of the Royal Society A: Mathematical, Physical and Engineering Sciences, 369(1938), 842-867.

Trostle, J. A. (2005). Epidemiology and culture. Cambridge University Press.

Ullman, D. (1979). Holistic health as a model for personal and social change. $\mathrm{C} / \mathrm{O}$ : Journal of Alternative Human Services, 5(2), 9-12.Vermeir, K. (2020). Editorial: Doing history in the time of COVID-19. Centaurus, 62, 219-222.

United Nations Development Programme (2020). Human Development Report 2020. UNDP.

Whiting, K. (2020). A Science journalist explains how the Spanish flu changed the world. World Economic Forum. https://www.weforum.org/agenda/2020/04/ covid-19-how-spanish-flu-changed-world/World Health Organization [WHO]. (2020).

COVID-19: Public Health emergency of international concern. WHO.

Wiersinga, W. J., Rhodes, A., Cheng, A. C., Peacock, S. J., \& Prescott, H. C. (2020). Pathophysiology, transmission, diagnosis, and treatment of coronavirus disease 2019 (COVID-19): A Review. JAMA Health Forum, 324(8), 782-793.

Worldometers. (2020). https://www.worldometers.info. [accessed 2020 November 22]. Retrieved from: https:// www.worldometers.info/coronavirus

Madhusudan Subedi (https://orcid.org/0000-0001-64950601) is Professor and Chairperson of the Department of Community Health Sciences and Co-ordinator of the School of Public Health, Patan Academy of Health Sciences, Nepal.

Email: madhusudansubedi@gmail.com 